\title{
AZ MTA FÖLDTUDOMÁNYOK OSZTÁLYÁBA TARTOZÓ TUDOMÁNYOS BIZOTTSÁGOK PUBLIKÁCIÓS KARAKTERISZTIKÁJÁNAK ÖSSZEHASONLÍTÓ ELEMZÉSE
}

\author{
CSOMÓS GYÖRGY

\begin{abstract}
A COMPARATIVE ANALYSIS OF THE PUBLICATION CHARACTERISTICS OF
SCIENTIFIC COMMITTEES CLASSIFIED INTO THE SECTION OF

EARTH SCIENCES OF THE HUNGARIAN ACADEMY OF SCIENCES
\end{abstract}

\begin{abstract}
This paper provides a comparative analysis of the discipline-specific publication characteristics of the Section of Earth Sciences of the Hungarian Academy of Sciences. The analysis focuses in particular on an evaluation of the following aspects: the publication output of individual researchers, co-author characteristics, international visibility, and the citation impact of the publications. The main goals of the analysis are as follows: 1) to justify that, on the basis of the discipline specific publication characteristics, the Section is considered to be inhomogeneous, and 2) to demonstrate that the discipline-specific inhomogeneity is not appropriately acknowledged by the Section's scientometric requirements that need to be fulfilled to obtain the title 'DSc'. The results of this analysis point to the clear need for a more accurate re-evaluation of the Section's scientometric requirements, and at the very least should inspire the leadership of the Section to implement more thorough comparative analysis focusing on the investigation of discipline-specific publication characteristics.
\end{abstract}

Keywords: earth sciences, MTMT, scientific publication, citations, scientometrics

\section{Bevezetés}

A Földrajzi Közlemények korábbi számában megjelent közleményemben (Csomós Gy. 2019) a társadalomföldrajz tudományrendszertani besorolásának hazai és nemzetközi gyakorlatát vázoltam. Abban a tanulmányban arra hívtam fel a figyelmet - és ez játszik a jelen munkában központi szerepet -, hogy a földtudományokkal foglalkozó kutatók egyéni publikációs sajátosságainak és teljesítményének szisztematikus elemzése jelentősen (szükségszerúen) hozzájárulhat az MTA X. Földtudományok Osztálya tudományos bizottságainak bizottsági szintú (szakterületi) tudománymetriai követelményrendszerének (újra)formálásához. Az MTA doktori habitusvizsgálata tudománymérési követelményeinek aktualizálását ugyanis nemcsak belső igények motiválják, hanem azt a rendszeresen felmerülő tudománypolitikai változások is kikényszerítik (lásd pl. az impakt faktor használhatósága körüli problémákat, vagy legújabban a Scopus adatbázis magyarországi előfizetésének lemondását). A kérdés tehát egyszerúbben megfogalmazva a következő: milyen a különböző tudományos bizottságokba tartozó (pontosabban az egyes szakterületeket múvelő) kutatók publikációs karakterisztikája, és milyen bizottsági szintű hasonlóságok, vagy különbségek mutathatók ki a tudományos publikálás sajátosságaiban?

Tanulmányomban a Földtudományok Osztálya tudományos bizottságaiban szereplő kutatók tudományos publikációit vizsgálom, a következtetéseimet pedig a bizottsági szinten összesített adatokból vonom le. Mielôtt azonban rátérek az elemzés érdemi részére, szükséges néhány gondolatot szentelni a felhasznált adatbázisoknak, a módszereknek, és magának a Földtudományok Osztályának. 


\section{Adatok és módszerek}

A Földtudományok Osztálya a Magyar Tudományos Akadémia tízedik osztálya, gondozott szakterületei pedig a következők: ásványtan, bányászat, földtan, geodézia, geoinformatika, geofizika, geokémia, kőzettan, meteorológia, őslénytan, társadalomföldrajz és természetföldrajz (https://mta.hu/x-osztaly/bemutatkozik-a-x-osztaly-105440). Az osztályba 11 tudományos bizottság tartozik, amelyek közül kettő (az Antropológiai Osztályközi Tudományos Bizottság és Mikrobiológiai Osztályközi Tudományos Bizottság) ún. osztályközi tudományos bizottság. A jelen elemzésben praktikus okok miatt - az osztályközi bizottságok által képviselt szakterületek nem kerülnek nevesítésre az osztály doktori habitusvizsgálatának tudománymérési követelményei között - csak kilenc tudományos bizottság jelenik meg, ezek a következők: Bányászati, Földtani, Geodéziai és Geoinformatikai, Geofizikai Geokémiai, Ásvány- és Kőzettani, Meteorológiai, Paleontológiai, Társadalomföldrajzi és Természetföldrajzi Tudományos Bizottság.

A kilenc tudományos bizottságnak - amelyek végső soron a Földtudományok Osztálya önmaga által meghatározott tudományos profilját jelenítik meg - az MTA Köztestületi Adattára szerint 2018. december 31-én 805 köztestületi tagja volt. Szükséges továbbá megemlíteni, hogy jelen tanulmányban - éppen a Földtudományok Osztálya fenti rendszertani besorolásának tükrében - a bizottság és a szakterület kifejezések lényegében szinonimaként használatosak. A feltételezés tehát az, hogy például a Köztestületi Adattárban a Geofizikai Tudományos Bizottsághoz sorolt kutató a geofizika szakterülettel foglalkozik, és a közleményei geofizika szakterületen jelennek meg. Ez nyilván nem feltétlenül van így a valóságban, ám a publikációk szakterületi besorolása fizikailag és technikailag lehetetlen, hiszen a szerzők nem jelölik a közleményeiken, hogy azok rendszertanilag milyen szakterület(ek)re sorolhatók be.

A tudománymetriai adatok feltérképezéséhez a Magyar Tudományos Múvek Tárát (MTMT) használom, bár azt meg kell jegyezni, hogy a nagy publikációs (indexelő) adatbázisok közül legkevésbé az MTMT alkalmas tudománymetriai kutatásokhoz. El kell természetesen fogadni a tényt, hogy nincs tökéletes publikációs adatbázis, nem nevezhetô annak sem a Web of Science, sem a Scopus, sem a Google Scholar. Tanulmányomban nem célom azt fejtegetni, hogy melyik adatbázisnak milyen előnyei és hátrányai vannak, azonban néhány gondolatot érdemes velük kapcsolatban megjegyezni.

A bibliometriai és tudománymetriai kutatásokat végző szakemberek leggyakrabban használt indexelő adatbázisa a Web of Science (WoS), amely a geográfia és általában a földtudományok nemzetközi bibliometriai tanulmányozásában is nagy jelentőségú (l. többek között Rey-Rocha, J.-Martín-Sempere, M. J. 2004, Coomes, O. T. et al. 2013, Wang, L.-LiU, Z. 2014, GorRaiz, J. et al. 2016 stb.). Az adatbázis megbízhatósága mellett nagy előnye, hogy kiegészül a bibliometriai adatok feldolgozását támogató online platformokkal is, mint például az InCites vagy az Essential Science Indicators. A WoS használata tehát ideális választás lenne, ha nem szembesülnénk két komoly hátrányával (legalábbis a magyar kutatók egy részének szemszögéből nézve): egyrészt az adatbázis által indexelt publikációk 64\%-a folyóiratcikk, másrészt az adatállományban erősen felülreprezentáltak az angol nyelvú publikációk (Mongeon, P.-PAul-Hus, A. 2016). Az utóbbi tényezó különösen problémásnak tûnik, hiszen alapvetően a természettudományi irányultságú szakterületeknek kedvez, szemben többek között a társadalomtudományi beállítottságú szakterületekkel (a késóbbiekben erre a problémakörre külön is kitérek).

A Scopus és a Google Scholar (főleg az utóbbi) sokkal kevésbé „elfogult” adatbázisok, viszont az adatgyújtésük módszertana és az idézések kezelése sem feltétlenül akkurátus. A Google Scholar egy algoritmus alapján, utólagos ellenőrzés nélkül indexeli a publiká- 
ciókat és számolja az idézéseket, következésképpen meglehetősen megbízhatatlan (a problémáról részletesebben ír pl. a King's College London [2019] könyvtára). Az Elsevier által üzemeltetett Scopus a WoS-hoz képest messze nagyobb publikációs körből állítja össze a portfólióját (bár esetében is uralkodó az angol nyelv, korántsem olyan mértékben, mint a WoS-ban), bizonyos esetekben több adatot is szolgáltat a WoS-nál (pl. városszintű affiliációs adatok is elérhetôk benne), azonban a tudományos életben mégsem tudott teret hódítani. A jelen elemzés szempontjából egyébként nagyjából ugyanazt a problémát mutatja, mint a WoS: túlzott folyóirat-centrikusság és még mindig erős angolnyelv-túlsúly. Továbbá jelenleg a legnagyobb probléma a Scopus használatával kapcsolatban az, hogy 2019. január 11. óta Magyarországon az egyetemek számára nem érhető el.

A WoS, a Scopus és a Google Scholar tehát kizárható publikációs adatbázisok, szemben az MTMT-vel, amely a hazai kutatók által bármilyen nyelven készített és bármilyen dokumentumtípusba tartozó publikációk legszélesebb körú adatbázisa (HoLl A. et al. 2014), és sok szempontból tökéletes választás lehetne a magyar kutatók publikációs karakterisztikájára és teljesítményére összpontosító bibliometriai elemzésekhez. Az MTMT-nek ugyanakkor létezik egy roppant kritikus eleme, ami nem más, mint az önkéntes adatfeltöltés. Szemben a korábban említett publikációs adatbázisokkal az MTMT feltöltése nem automatikusan történik, illetve nem egy szerkesztői team feladata azt megtenni, hanem a kutatók (vagyis a szerzők) egyéni felelőssége. Mindez két komoly problémát eredményez: egyrészt a kutatók egy tekintélyes csoportjának egyszerúen nincs MTMT-profilja, azaz ha publikálnak is (ami azért elég valószínű), annak az MTMT-ben nincs nyoma; másrészt - és ez még az előző problémánál is fajsúlyosabbnak túnik - az MTMT-be feltöltött adatok hitelessége megkérdőjelezhetô (az okok itt és most lényegtelenek), vagyis egy lezárást követő felülvizsgálatig (mint amilyet pl. az MTA doktori cím megszerzése megkövetel) a feltöltött adatok még az MTMT-adminisztrátorok láttamozása mellett sem feltétlenül tekinthetők korrekteknek. Az MTMT használatát tehát jelen esetben nem az adatbázisban szereplő adatok minősége, hanem a puszta kényszer motiválja, és az adatbázis fent vázolt negatívumát az elemzés során mindvégig szem előtt kell tartani.

Az elemzés egy ötéves időablakban történik: minden szerző esetében kizárólag a 2013 és 2017 közötti megjelent bármely típusú, az MTMT-ben tudományosként definiált publikációkat vettem figyelembe. Az időintervallum kijelölésének oka egyértelmú: szükségszerű egy korlátozott periódusban vizsgálni a kutatók publikációs aktivitását, és nem ,életmúvekre" összpontosítani, egy pályakezdő fiatal kutató teljes publikációs kibocsátását ugyanis nyilván nem érdemes egy senior kutató kibocsátásával összehasonlítani. Az idézéselemzés során viszont a 2013-2018-as periódusban keletkezett és 2018. december 31-ig rögzített idézésekkel számolok, amelynek alapvetôen technikai okai vannak, pl. az, hogy MTMT-ben az idézésekre nem lehet szűrni.

A következőkben tehát a Földtudományok Osztály kilenc tudományos bizottságához tartozó (pontosabban a különböző szakterületeket múvelő) kutatók 2013 és 2017 közötti, bizottsági szinten kumulált publikációs karakterisztikáját és teljesítményét, továbbá idézettségi hatását mutatom be. Egy speciális összehasonlító vizsgálat érdekében (amelynek okát a későbbiekben részletezem) a Regionális Tudományok Bizottsága is részét képezi az elemzésnek, adatai feltûnnek a táblázatokban és egyes ábrákban.

\section{Eredmények}

Az MTMT tehát a magyar tudományos élet elsődleges publikációs adatbázisa: feltöltöttsége nélkülözhetetlen munkahelyi előresorolásokhoz, előfeltétele fokozat $(\mathrm{PhD})$ vagy címek (habilitáció, MTA doktora) megszerzésére indított eljárásoknak, és az MTMT-t 
szokás figyelembe venni hazai tudományos és egyéb pályázatok (pl. Bolyai János Kutatási Ösztöndíj, EFOP stb.) benyújtása, illetve a projektek teljesítettségének értékelése estében is. Mint azt korábban említettem, az MTMT-profil létrehozása és feltöltése önkéntes, és bár a fenti okok miatt azt várhatnánk, hogy az mindenkinek érdekében is áll, valójában mégis az tapasztalható, hogy a kutatók egy nem is elhanyagolható része nem szerepel az MTMT adatbázisban. Természetesen változatos és egyéntől függő okokra vezethetô az vissza, hogy miért nincs egy kutatónak MTMT-profilja, bár az adatok alapján azért óvatos következtetések megengedhetők. Az MTA Köztestületi Adattára (amelybe egyébként szintén önkéntes a jelentkezés) a Földtudományok Osztályában 805 kutatót tart nyilván, ám az MTMT átvizsgálása után kiderült, hogy közülük mindössze 585 kutató rendelkezik MTMT-profillal. Mint az 1. táblázatban látható, az osztály tagjainak valamivel kevesebb mint háromnegyede hozott létre MTMT-profilt, a legmagasabb, $80 \%$ feletti értékek pedig a Társadalomföldrajzi és a Természetföldrajzi Tudományos Bizottságok esetében mutathatók ki. Ezt a tényt érdemes figyelembe venni, hiszen ez a két bizottság rendelkezik a legtöbb taggal (a két bizottság az osztály tagjainak 36\%-át adja), vagyis összességében felfelé húzzák az osztályra jellemző tag/MTMT-profil arányt.

1. táblázat-Table 1

A tagok száma és az MTMT-profillal rendelkező tagok száma, valamint arányuk

a Földtudományok Osztálya egyes tudományos bizottságaiban (2018)

The number of members and the members having MTMT profile and their proportion in certain scientific committees of the Section of Earth Sciences

\begin{tabular}{|c|c|c|c|}
\hline Tudományos bizottság & $\begin{array}{c}\text { Tagok száma } \\
\text { az MTA } \\
\text { Köztestületi } \\
\text { Adattár szerint }\end{array}$ & $\begin{array}{c}\text { MTMT-profillal } \\
\text { rendelkezó } \\
\text { tagok száma }\end{array}$ & $\begin{array}{c}\text { MTMT-profillal } \\
\text { rendelkező tagok } \\
\text { aránya az összeshez } \\
\text { képest }(\%)\end{array}$ \\
\hline $\begin{array}{l}\text { Bányászati } \\
\text { Tudományos Bizottság }\end{array}$ & 65 & 33 & 50,77 \\
\hline $\begin{array}{l}\text { Földtani } \\
\text { Tudományos Bizottság }\end{array}$ & 75 & 51 & 68,00 \\
\hline $\begin{array}{l}\text { Geodéziai és } \\
\text { Geoinformatikai } \\
\text { Tudományos Bizottság }\end{array}$ & 57 & 38 & 66,67 \\
\hline $\begin{array}{l}\text { Geofizikai } \\
\text { Tudományos Bizottság }\end{array}$ & 80 & 48 & 60,00 \\
\hline $\begin{array}{l}\text { Geokémiai, Ásvány- } \\
\text { és Kôzettani } \\
\text { Tudományos Bizottság }\end{array}$ & 107 & 81 & 75,70 \\
\hline $\begin{array}{l}\text { Meteorológiai } \\
\text { Tudományos Bizottság }\end{array}$ & 84 & 56 & 66,67 \\
\hline $\begin{array}{l}\text { Paleontológiai } \\
\text { Tudományos Bizottság }\end{array}$ & 45 & 33 & 73,33 \\
\hline $\begin{array}{l}\text { Társadalomföldrajzi } \\
\text { Tudományos Bizottság }\end{array}$ & 174 & 148 & 85,06 \\
\hline $\begin{array}{l}\text { Természetföldrajzi } \\
\text { Tudományos Bizottság }\end{array}$ & 118 & 97 & 82,20 \\
\hline $\begin{array}{l}\text { Földtudományok } \\
\text { Osztálya összesen }\end{array}$ & 805 & 585 & 72,67 \\
\hline
\end{tabular}


Mint azt korábban kifejtettem, az MTMT-profil létrehozásának, pontosabban nem létrehozásának okaira csak nagyvonalú következtetések engedhetők meg (azt többek között személyes okok is motiválhatják), mindenesetre egy jelenségre érdemes felhívni a figyelmet. Az MTMT-profillal rendelkezők esetében az első tudományos fokozat ( $\mathrm{PhD}$, kandidátus, tudományok doktora) megszerzésének mediánja 2004, a szélső értékek 1974 és 2018, míg az MTMT-profillal nem rendelkező kutatók esetében ez az érték 1995, a szélső értékek pedig 1961 és 2018 (1.és 2. ábra). Kijelenthető, hogy az MTMT-profillal nem rendelkező kutatók bár nem kizárólagosan, de alapvetően korábban szereztek valamilyen tudományos

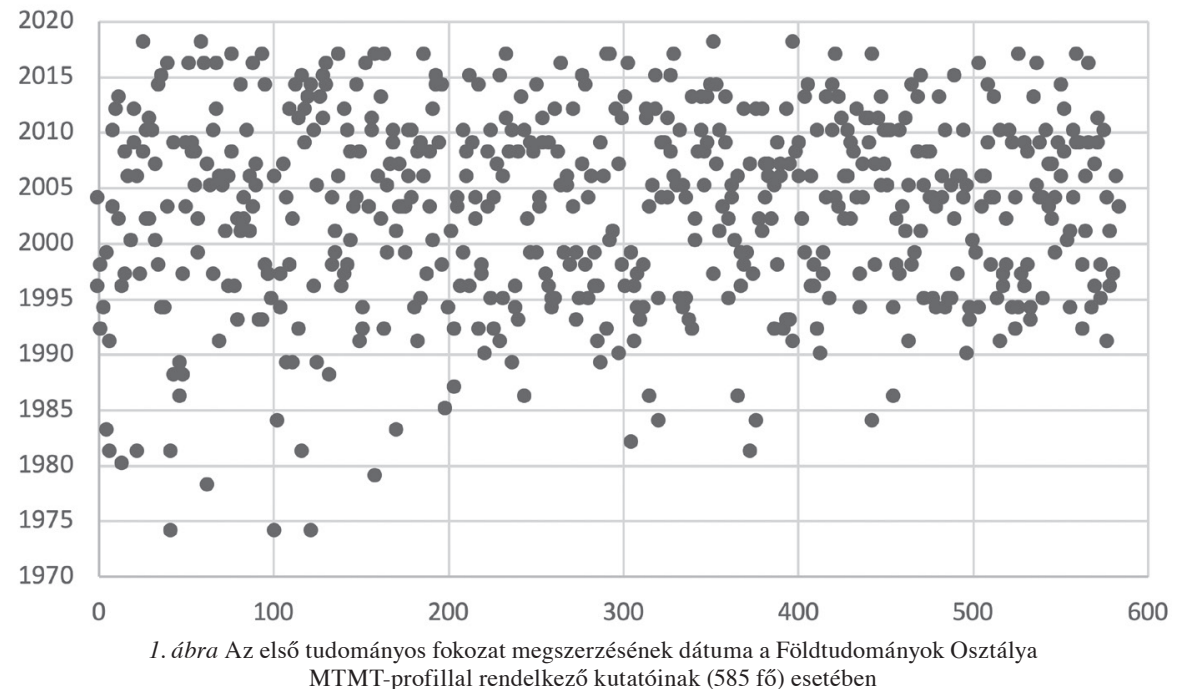

Figure 1 The date when the first scientific degree was awarded to researchers being the member of the Section of Earth Sciences and having MTMT profile (585 persons)

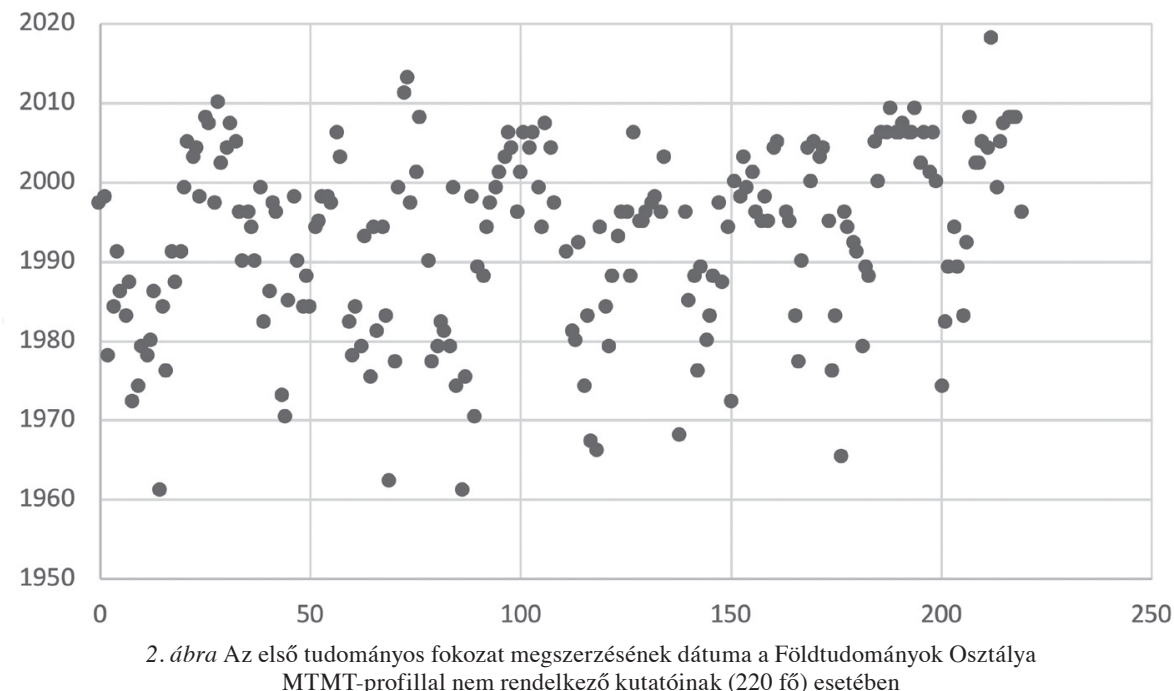

Figure 2 The date when the first scientific degree was awarded to researchers being the member of the Section of Earth Sciences and not having MTMT profile (220 persons) 
minősítést (legalábbis a Köztestületi Adattárban elérhető nem feltétlenül pontos információk szerint), mint az MTMT-profilt létrehozók. Az MTMT korosztályos hovatartozástól függő használatára hívja fel a figyelmet PROBÁLD F. (2018) is, aki lényegében szintén arra a következtetésre jut, hogy „,a fiatalabb kutatók számára már gyakorlatilag kötelezővé, a köztestületi tagság és a különféle pályázatok elemi követelményévé vált közleményeik feltöltése az MTMT-be" (p. 250).

Az elemzésbe tehát a potenciálisan figyelembe vehető 805 kutatóból 585 került bevonásra, az ő publikációs karakterisztikájukat vizsgáltam meg, ami konkrétan azt jelenti, hogy minden egyes kutató minden egyes 2013 és 2017 között megjelent és az MTMT-ben rögzített tudományos publikációját egyesével áttekintettem.

\section{Publikációs kibocsátás}

A Földtudományok Osztálya kutatói a 2013-2017 közötti időszakban (hangsúlyozva ismét, hogy kizárólag az MTMT feltöltöttségét figyelembe véve) összességében 18073 tudományos publikációt jelentettek meg. Messze a legtöbb publikáció - az osztály teljes publikációs kibocsátásának 23,49\%-a - a Társadalomföldrajzi Tudományos Bizottságban keletkezett (3.ábra). (Mindössze a nagyságrendek szemléltetése érdekében megemlítendő, hogy a Társadalomföldrajzi Tudományos Bizottság kutatói a vizsgált időszakban több publikációt készítettek, mint a Bányászati, a Geodéziai és Geoinformatikai, a Paleontológiai és a Geofizikai Tudományos Bizottságok kutatói együttesen.) Önmagában a kibocsátás nyers adatainak bemutatása persze kevés használható információt hordoz, hiszen az adott szakterület kutatónak átlagos egyéni tudományos teljesítményét a fajlagos értékek adják vissza.

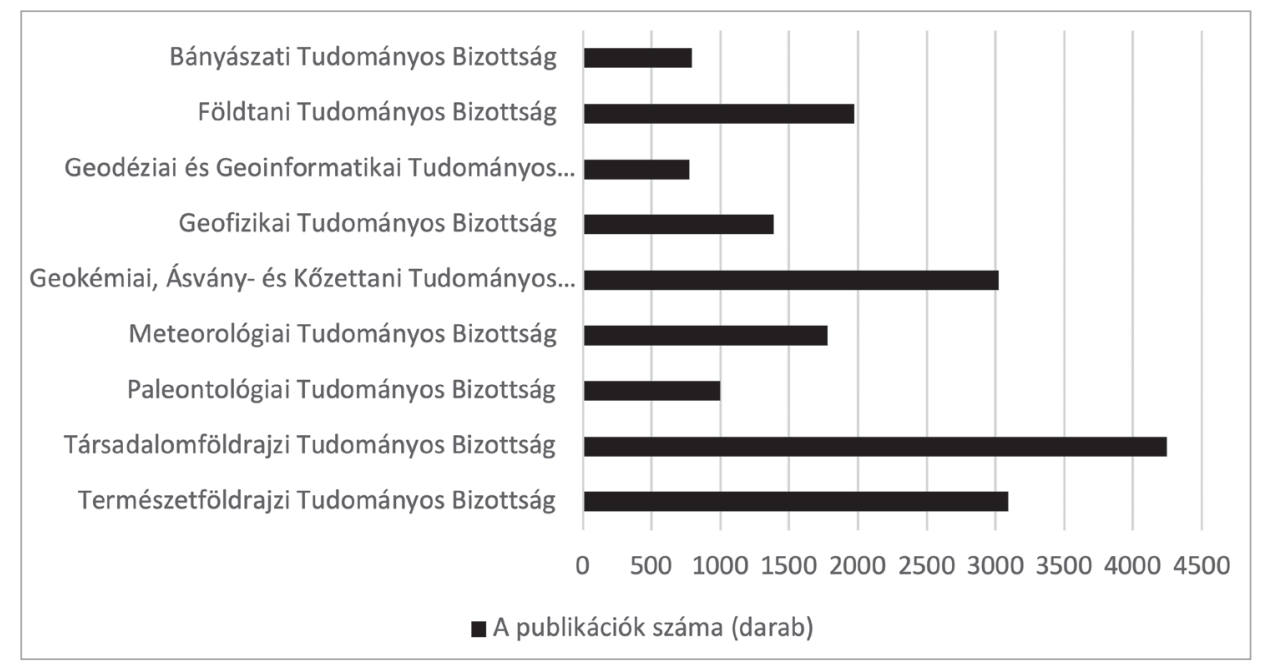

3. ábra A Földtudományok Osztálya egyes tudományos bizottságainak kumulált publikációs kibocsátása (2013-2017) Figure 3 The cumulative publication output of certain scientific committees of the Section of Earth Sciences (2013-2017)

A 4.ábra azt mutatja, hogy a Társadalomföldrajzi Tudományos Bizottság a fajlagos értékek tekintetében egyáltalán nem emelkedik ki a többi bizottság közül, sőt tulajdonképpen a 28,69 darab egy főre jutó átlagos publikációs számmal csak a Geodéziai és Geoinformatikai Tudományos Bizottságot (20,47 publikáció/fó) és a Bányászati Tudományos Bizottságot (23,97 publikáció/fő) előzi meg. A vizsgált időszakban az osztályátlag 


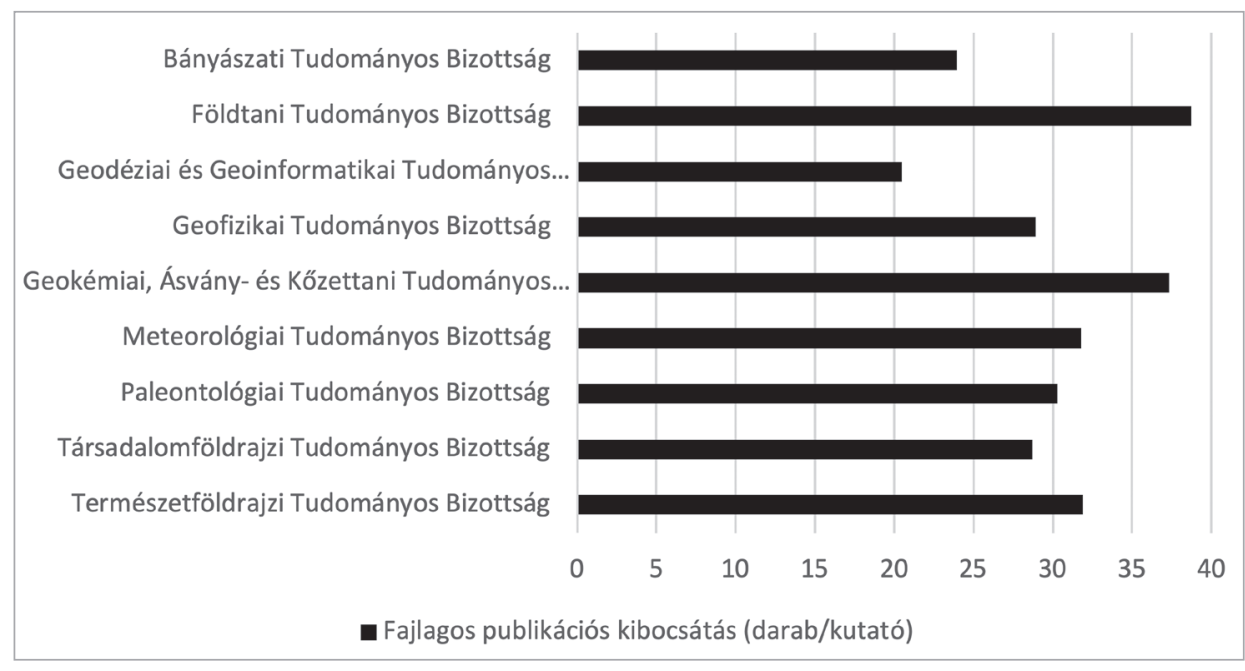

4. ábra A Földtudományok Osztálya egyes tudományos bizottságainak fajlagos (egy főre vetített átlagos) publikációs kibocsátása (2013-2017)

Figure 4 The per capita publication output of certain scientific committees of the Section of Earth Sciences (2013-2017)

30,89 publikáció/fó, amelynek értékét egyébként éppen a Társadalomföldrajzi Tudományos Bizottság nagy tagszáma és viszonylag alacsonyabb fajlagos értéke húzza le (igaz, nem jelentős mértékben).

Az osztályátlagot bőven meghaladó, közel azonos mértékủ fajlagos kibocsátással két erôsen természettudományi beállítottságú bizottság képviselői rendelkeznek: a Földtani Tudományos Bizottság kutatóinak egy főre jutó átlagos publikációs kibocsátása 5 évre vetítve 38,75 darab, míg a Geokémiai, Ásvány- és Kőzettani Tudományos Bizottság esetében ez az érték 37,33 darab.

Ezen a ponton meg kell megjegyezni, hogy a geodézia és geoinformatika, a bányászat, de különösen a társadalomföldrajz szakterület esetében az alacsonyabb fajlagos kibocsátás messze nincs összhangban a MTA doktori habitusvizsgálat tudománymérési követelményeivel: például a társadalomföldrajz szakterületen minimumkövetelményként megállapított 40 tudományos közlemény 33\%-kal több, mint más, egyébként nagyobb fajlagos kibocsátással rendelkező szakterület esetében. Másképpen megközelítve: a jelen elemzésben kimutatott szakterület-specifikus publikációs dinamika alapján az állapítható meg, hogy az egyes szakterületeket múvelő kutatóknak a valóságban roppant eltérő idő szükséges a számukra megállapított minimumkövetelmények teljesítéséhez (5.ábra). A földtannal foglalkozó kutatók - figyelembe véve a szakterületre jellemző fajlagos kibocsátást - átlagosan 3,87 év alatt elérik a minimumkövetelményként előírt darabszámot, míg a geodézia és geoinformatika szakterületet múvelőknek ehhez majdnem dupla annyi idő, 7,33 év szükséges. Bár a minimumkövetelmény értéke eltérő, mégis egyaránt magasan átlag feletti - az átlag osztályszinten 4,86 év - idő, 6,26, illetve 6,97 év szükséges a bányászattal és a társadalomföldrajzzal foglalkozó kutatóknak is, hogy teljesítsék a számukra meghatározott minimumkövetelmény darabszámát.

Természetesen a szakterület-specifikus áltagos fajlagos kibocsátás messze nem tükrözi az egyéni teljesítményeket, de legalább támpontot nyújt a doktori habitusvizsgálat tudománymérési követelményeiben minimumként megfogalmazott darabszámok pontosításához. 


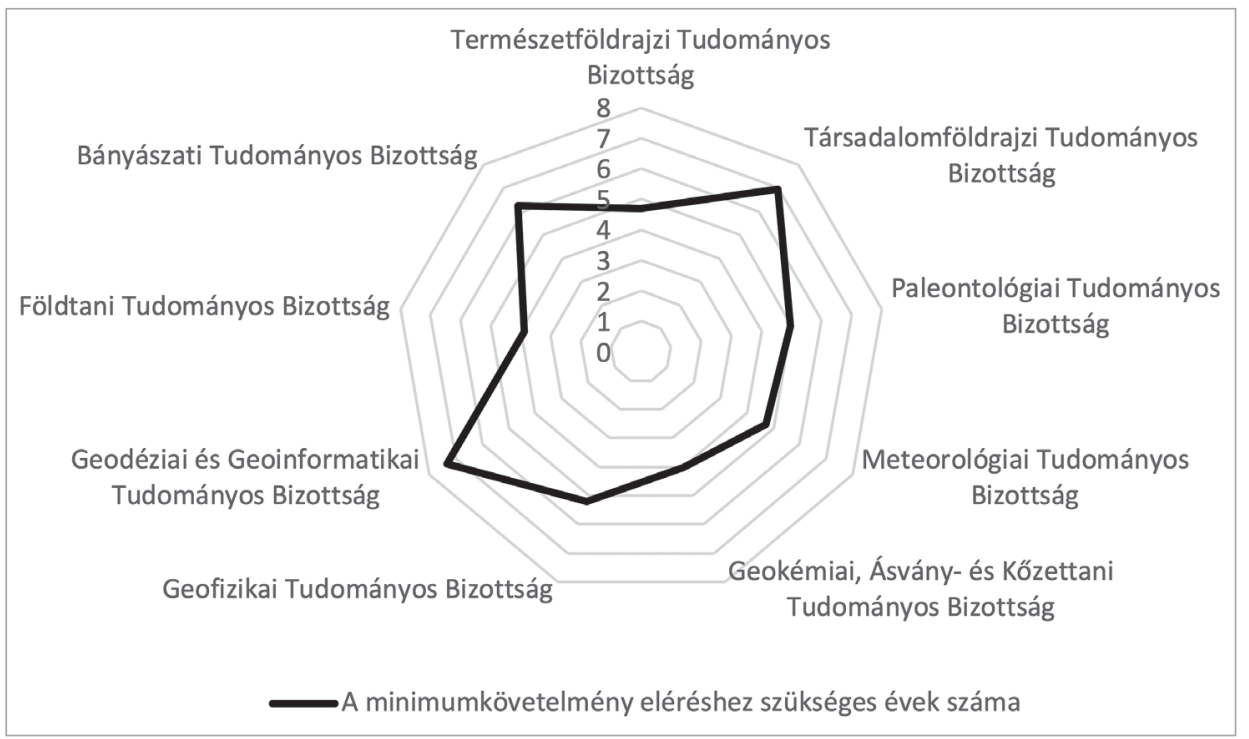

5. ábra A szakterület-specifikus fajlagos kibocsátás alapján kimutatható évek száma,

amelyek a doktori habitusvizsgálat tudománymérési követelményei által minimumkövetelményként megfogalmazott publikációszám (teljes tudományos közlemény) eléréshez szükségesek

Figure 5 The expected numbers of years that are needed to accomplish the minimum number of publications indicated in the doctoral regulation of the Section of Earth Sciences

\section{Társszerzöség}

Joggal merül fel a kérdés, hogy mi az oka a fajlagos kibocsátásban mutatkozó jelentős eltéréseknek. A magyarázat pedig részben az, hogy a természettudományok esetében a társszerzős közlemények aránya, valamint az átlagos publikációnkénti társszerző-szám rendszerint sokkal magasabb, mint a társadalomtudományok területén (NEWMAN, M. E. 2001, MALI, F. et al. 2012). Nem arról van tehát szó, hogy egy természettudományi megközelítésú publikáció kevesebb energiabefektetéssel vagy éppen gyorsabban készül el, mint egy társadalomtudományi irányultságú (főleg, hogy a publikálást megelőző kutatási tevékenység és a publikálás folyamatának teljes időtartama az esetek többségében nem is ismert), az viszont nagy biztonsággal kijelenthető, hogy a természettudományi szakterületeket művelő kutatók potenciálisan több tudományos publikációban vehetnek részt társszerzőként, mint a társadalomtudományokkal foglalkozó társaik. Hogy a fenti összefüggés nem pusztán hipotézis, azt a következő, a társszerzőségre összpontosító vizsgálat igazolja. A társszerzős közlemények száma az egyéni publikációs kibocsátás kumulálásával kerül meghatározásra annak érdekében, hogy párhuzamba állítható legyen az osztály- és bizottsági szintű kibocsátással.

Kezdjük először néhány kevésbé használható, de annál látványosabb adat bemutatásával (2. táblázat): a Földtudományok Osztálya kutatói a 2013-2017-es időszakban 15144 társszerzős publikációt jelentettek meg (ez a teljes publikációs kibocsátás 83,79\%-a), amelyekben összesen 63817 társszerző múködött közre (ez a szám csak a publikációk társszerzőinek számára utal, és nem tartalmazza azt a szerzőt, akinek a publikációs listája feldolgozásra került). A társszerzős cikkek esetében az egy cikkre jutó társszerzők száma tehát 4,21. Ennél persze messze sokatmondóbb az adatokat a szakterületek szintjén megvizsgálni. 
2. táblázat-Table 2

A Földtudományok Osztálya (és a Regionális Tudományok Bizottsága) kutatói által megjelentett publikációk társszerzőséggel kapcsolatos adatai bizottságonként (2013-2017) The co-author characteristics of publications produced by researchers of the Section of Earth Sciences (and that of the Regional Science Committee) by committees (2013-2017)

\begin{tabular}{|c|c|c|c|c|}
\hline Tudományos bizottság & $\begin{array}{c}\text { Társszerzős } \\
\text { publikációk } \\
\text { száma } \\
\text { összesen }\end{array}$ & $\begin{array}{c}\text { Társszerzős } \\
\text { publikációk } \\
\text { aránya az } \\
\text { összeshez } \\
\text { képest (\%) }\end{array}$ & $\begin{array}{c}\text { Társszerzők } \\
\text { száma1 } \\
\text { a társszerzős } \\
\text { publikációkban } \\
\text { összesen }\end{array}$ & $\begin{array}{c}\text { Átlagos } \\
\text { társszerzószám } \\
\text { a társszerzős } \\
\text { publikációkban }\end{array}$ \\
\hline $\begin{array}{l}\text { Bányászati } \\
\text { Tudományos Bizottság }\end{array}$ & 607 & 76,74 & 2110 & 3,48 \\
\hline $\begin{array}{l}\text { Földtani } \\
\text { Tudományos Bizottság }\end{array}$ & 1847 & 93,47 & 7908 & 4,28 \\
\hline $\begin{array}{l}\text { Geodéziai } \\
\text { és Geoinformatikai } \\
\text { Tudományos Bizottság }\end{array}$ & 561 & 72,11 & 2083 & 3,71 \\
\hline $\begin{array}{l}\text { Geofizikai } \\
\text { Tudományos Bizottság }\end{array}$ & 1286 & 92,72 & 6965 & 5,42 \\
\hline $\begin{array}{l}\text { Geokémiai, Ásvány- } \\
\text { és Kőzettani } \\
\text { Tudományos Bizottság }\end{array}$ & 2885 & 95,40 & 16259 & 5,64 \\
\hline $\begin{array}{l}\text { Meteorológiai } \\
\text { Tudományos Bizottság }\end{array}$ & 1644 & 92,31 & 6799 & 4,14 \\
\hline $\begin{array}{l}\text { Paleontológiai } \\
\text { Tudományos Bizottság }\end{array}$ & 841 & 84,18 & 3321 & 3,95 \\
\hline $\begin{array}{l}\text { Társadalomföldrajzi } \\
\text { Tudományos Bizottság }\end{array}$ & 2746 & 64,67 & 7515 & 2,74 \\
\hline $\begin{array}{l}\text { Természetföldrajzi } \\
\text { Tudományos Bizottság }\end{array}$ & 2727 & 88,22 & 10857 & 3,98 \\
\hline $\begin{array}{l}\text { Földtudományok } \\
\text { Osztálya összesen }\end{array}$ & 15144 & 83,79 & 63817 & 4,21 \\
\hline $\begin{array}{l}\text { Regionális } \\
\text { Tudományok Bizottsága }\end{array}$ & 2476 & 62,07 & 5523 & 2,23 \\
\hline
\end{tabular}

${ }^{1}$ A társszerzős publikációk esetében a társszerzők számába nem tartozik bele az a szerző, akinek az MTMT-profilja feldolgozásra került. Ez a kitétel a társszerzős publikációnkénti átlagos társszerzőszámot is befolyásolja (csökkenti).

Ahogy korábban már bebizonyosodott, az abszolút értékek helyett a fajlagos adatokból kinyerhetô információkkal érdemes foglalkozni. Mint a 2. táblázatban látható, a társszerzős publikációk aránya mindössze három bizottság esetében marad az osztályátlag alatt, míg négy bizottság magasan az átlag feletti értékekkel rendelkezik. A Geokémiai, Ásvány- és Kőzettani Tudományos Bizottság kutatói által jegyzett publikációk 95,4\%-a társszerzős formában készül, ami több mint 10\%-kal haladja meg az osztályátlagot. Ezzel szemben a Társadalomföldrajzi Tudományos Bizottság kutatói csak a publikációik 64,67\%-át készítik el társszerzős formában. Lényegében hasonló különbségek tapasztalhatók a publikációnkénti társszerzőszámban is: az osztályátlagot három bizottság értéke haladja meg, közülük a Geokémiai, Ásvány- és Kőzettani, valamint a Geofizikai Tudományos Bizottság magasan 
(átlagosan 5,64, illetve 5,42 társszerző/publikáció). Ezzel szemben a Társadalomföldrajzi Tudományos Bizottság átlagos társszerző/publikáció értéke $(2,74)$ messze legnagyobb mértékben az osztályátlag alatt áll. A 4. ábra és a 2. táblázat adatainak összevetése után kijelenthető, hogy elsősorban valóban azokon a szakterületeken magas a fajlagos publikációs kibocsátás, amelyeken magas a társszerzős publikációk aránya (ráadásul magas a publikációnkénti átlagos társszerzőszám is). A Földtani Tudományos Bizottság esetében a publikációs kibocsátás egy fớre jutó átlaga a vizsgált időszakban 38,75 darab volt (első hely), ugyanez a Geokémiai, Ásvány- és Kőzettani Tudományos Bizottság esetében 37,33 darabos értéket ért el (második hely). A 2. táblázatból látható, hogy ez a két bizottság a társszerzős publikációk arányának tekintetében is az élen áll. Velük ellentétben a Társadalomföldrajzi Tudományos Bizottságban alacsony a fajlagos publikációs kibocsátás (igaz, nem a legalacsonyabb, mert a Geodéziai és Geoinformatikai, valamint a Bányászati Tudományos Bizottságé kisebb), és alacsony az átlagos társszerző/publikáció arány is.

A társszerzőséggel kapcsolatban felmerülő másik kérdés az, hogy a társszerzős publikációk arányát, illetve az átlagos társszerző/publikáció számot figyelembe véve kijelenthetjük-e egy földtudományi szakterületről, hogy a publikációs karakterisztikája inkább a társadalomtudományokhoz áll közelebb? Erre a kérdésre azonban korántsem egyszerú válaszolni, hiszen ez egy újabb kérdést vet fel: mihez kívánjuk az egyik vagy másik szakterület publikációs sajátosságait hasonlítani? Szükséges volt tehát egy nem a Földtudományok Osztályba tartozó szakterület kutatóinak publikációs teljesítményét is megvizsgálni ugyanazokkal a módszerekkel, mint ahogyan a többi esetében történt. Ez a szakterület pedig a regionális tudományok, amelyet tudományos bizottság szintjén a Gazdaság- és Jogtudományok Osztályába tartozó Regionális Tudományok Bizottsága képvisel. A közgazdaságtan, a jogtudományok és a regionális tudományok - akár nemzetközi, akár hazai szinten vizsgáljuk - egyaránt döntően társadalomtudományokként számon tartott szakterületek (HANSEN, N. M.-Quigley, J. M. 1976, IsARD, W. 2003, ProbÁLD F. 2007). A 2. táblázat alapján összehasonlíthatók a Társadalomföldrajzi Tudományos Bizottság és a Regionális Tudományok Bizottsága megfelelő adatai. Ebben az esetben elsôsorban a fajlagos értékeknek van jelentôsége, és az egyértelmúen kivehetô az adatokból, hogy a társadalomföldrajz szakterület (bizottsági szinten a Társadalomföldrajzi Tudományos Bizottság) társszerzőséggel kapcsolatos tudománymetriai mutatói - figyelembe véve a Földtudományok Osztálya más bizottságainak jellemzőit is - közelebb állnak egy társadalomtudományként nevesített szakterület, konkrétan a regionális tudományok megfelelő mutatóihoz.

Összességében tehát megállapítható, hogy a tudományos publikációk társszerzősség-karakterisztikája alapján a Földtudományok Osztály inhomogén, a publikációnként sok társszerzővel dolgozó szakterületek esetében pedig jellemzően nagyobb a fajlagos kibocsátás.

\section{A folyóiratcikkek aránya és nemzetközi láthatósága}

A tudományos életben a folyóiratcikkeknek különleges jelentőségük van. Nyilvánvaló, hogy a kutatók egyéni publikációs teljesítményének kimutatásakor nem mellőzhetők a könyvek, a konferenciacikkek, földrajzosok esetében a térképek sem, ám BRAUN, T. et al. (1989) szerint az új tudás megismertetésének alapvetó eszköze mégiscsak a folyóiratcikk. A folyóiratcikkek megjelenhetnek hazai és nemzetközi folyóiratokban (bár a „nemzetköziség” definiálása nézópont kérdése). Utóbbiak közül kiemelkednek a Web of Science-ben indexelt folyóiratokban publikált cikkek (a WoS különböző indexelő adatbázisai jelentőségének elemzésétől itt most eltekintünk), a WoS ugyanis a leggyakrabban használt, sokak szerint a legnagyobb presztízsú indexelő adatbázis (lásd többek között JACsO, P. 2005, YANG, 
K.-Meho, L. I. 2007, Mongeon, P.-Paul-Hus, A. 2016, Maisonobe, M. et al. 2017), így a hazai kutatók tudományos munkásságának nemzetközi láthatósága is legalkalmasabb módon a WoS-ban indexelt cikkek számának összegzésén és idézettségi hatásának vizsgálatán keresztül mutatható ki (és vegyük figyelembe azt is, hogy a WoS el is érhető a magyarországi egyetemeken).

A 3.táblázat azt mutatja, hogy a 2013-2017-es időszakban az egyes szakterületek kutatói mennyi folyóiratcikket publikáltak, és abból mennyi volt a WoS-ban indexelt folyóiratcikk. Az abszolút értékek ismét csak tájékoztató jellegúek, a lényeg a fajlagos értékek mögött húzódik. Osztályszinten a folyóiratcikkek aránya az összes publikáció számához képest $38,1 \%$, vagyis az összes publikáció valamivel több mint egyharmada folyóiratokban jelent meg. Az összes publikációhoz képest arányait tekintve messze a legtöbb folyóiratcikket a Geodéziai és Geoinformatikai Tudományos Bizottság kutatói készítik, a bizottságszintű érték az 50\%-hoz közelít. Az ezt követô sorrend viszont érdekes kérdéseket vet fel. Többen is felhívják arra a figyelmet, hogy a társadalomtudományok esetében a publikációtípusok között nincs uralkodó helyzete a folyóiratcikknek, mivel a könyv és a könyvfejezet is elterjedt, szemben a természettudományokkal, amelyek erősen folyóirat-centrikusak (CSABA L. et al. 2014, SzEGEDY-MAszÁK M. 2015, Csomós Gy. 2016). Azt várhatnánk tehát, hogy a társadalomföldrajz - amelynek társadalomtudományi attitúdjét igazolta, vagy inkább megerősítette a társszerzóség-karakterisztika - viszonylag alacsony folyóiratcikk-aránnyal rendelkezik. Az eredmények azonban több mint meglepők: a társadalomföldrajz szakterületre a második legmagasabb, az osztályátlagot meghaladó összes publikáció/folyóiratcikk arány jellemző. Ennek az információnak az ismeretében leszögezhetjük, hogy míg a fajlagos kibocsátás, vagy a társszerzős publikációk aránya alapján a társadalomföldrajz a társadalomtudományokkal rokonítható, addig a folyóiratcikkek aránya tekintetében természettudományi szakterületeket is maga mögé utasítja. A jelenség okai összetettek, ám mindenféle előzetes kijelentés előtt szükséges megvizsgálni azt is, hogy a milyen a folyóiratcikkek nemzetközi láthatósága, vagyis az indexeltségi arányuk a WoS-ban.

A 3. táblázatban látható, hogy a Társadalomföldrajzi Tudományos Bizottság kutatói által publikált folyóiratcikkek alig 10\%-a indexelt a WoS-ban, míg ez az arány a Geokémiai, Ásvány-és Kőzettani Tudományos Bizottság esetében a 60\%-ot közelíti. Szintén viszonylag alacsony WoS-beli láthatósággal rendelkezik a Bányászati Tudományos Bizottság, és meglepő módon a Természetföldrajzi Tudományos Bizottság is. Pusztán az indikátorok értékét figyelembe véve nehéz megmagyarázni, hogy a vázolt jelenségnek mi az oka. A kielégítő magyarázat érdekében ugyanis minden egyes folyóiratcikk tartalmát és szerzői összetételét egyesével át kellene vizsgálni (ami - tekintettel az MTMT szúrési opcióira - fizikai képtelenség), és még úgy is csak nagyvonalú következtetések lennének levonhatók. A szakirodalom alapján annyi mindenestre megállapítható, hogy minél egzaktabb kutatási témával foglalkozik egy publikáció, annál könnyebben talál utat a nemzetközi olvasótáborral rendelkező folyóiratok felé (INGWERSEN, P. 2000). Elképzelhetó tehát, hogy a döntôen Magyarországot a középpontba állító társadalomföldrajzi, természetföldrajzi és talán a bányászati szakterület is a viszonylag szúk földrajzi korlátozottság miatt kerül a nemzetközi folyóiratok látószögén kívülre. Ezzel szemben az olyan egzaktabb, erősen természettudományi beállítottságú szakterületek, mint a földtan, geofizika, geokémia, meteorológia vagy paleontológia kevésbé szembesülnek a földrajzi korlátokból származó „diszkriminatív” hatásokkal (a kérdés nyilván és kizárólag a publikációs gyakorlat szempontjából kerül megközelítésre). A publikációk nyelvét részletesen vizsgáló elemzés hiányában messzemenő következtetések nem vonhatók le, ám az gyanítható, hogy minél alacsonyabb a folyóiratcikkek nemzetközi, azaz WoS-beli láthatóságának szintje, annál magasabb a magyar nyelven, hazai kiadásban, hazai célközönségnek szóló folyóiratcikkek 
A Földtudományok Osztálya (és a Regionális Tudományok Bizottsága) kutatói által publikált folyóiratcikkek néhány tudománymetriai jellemezője bizottsági szinten (2013-2017) Some bibliometric features of journal articles published by researchers of the Section of Earth Sciences (and that of the Regional Science Committee) by committees (2013-2017)

\begin{tabular}{|c|c|c|c|c|}
\hline Tudományos bizottság & $\begin{array}{c}\text { Folyóirat- } \\
\text { cikkek } \\
\text { száma } \\
\text { összesen }\end{array}$ & $\begin{array}{c}\text { Folyóiratcikkek } \\
\text { aránya } \\
\text { az összes } \\
\text { publikációhoz } \\
\text { képest (\%) } \\
\end{array}$ & $\begin{array}{c}\text { A WoS-ban } \\
\text { indexelt } \\
\text { folyóiratcikkek } \\
\text { száma } \\
\text { összesen } \\
\end{array}$ & $\begin{array}{l}\text { A WoS-ban } \\
\text { indexelt folyóirat- } \\
\text { cikkek aránya az } \\
\text { összes folyóirat- } \\
\text { cikkhez képest }(\%)\end{array}$ \\
\hline $\begin{array}{l}\text { Bányászati } \\
\text { Tudományos Bizottság }\end{array}$ & 255 & 32,24 & 46 & 18,04 \\
\hline $\begin{array}{l}\text { Földtani } \\
\text { Tudományos Bizottság }\end{array}$ & 614 & 31,07 & 299 & 48,70 \\
\hline $\begin{array}{l}\text { Geodéziai } \\
\text { és Geoinformatikai } \\
\text { Tudományos Bizottság }\end{array}$ & 383 & 49,23 & 121 & 31,59 \\
\hline $\begin{array}{l}\text { Geofizikai } \\
\text { Tudományos Bizottság }\end{array}$ & 555 & 40,01 & 249 & 44,86 \\
\hline $\begin{array}{l}\text { Geokémiai, Ásvány- } \\
\text { és Kőzettani } \\
\text { Tudományos Bizottság }\end{array}$ & 1132 & 37,43 & 659 & 58,22 \\
\hline $\begin{array}{l}\text { Meteorológiai } \\
\text { Tudományos Bizottság }\end{array}$ & 629 & 35,32 & 299 & 47,54 \\
\hline $\begin{array}{l}\text { Paleontológiai } \\
\text { Tudományos Bizottság }\end{array}$ & 380 & 38,04 & 174 & 45,79 \\
\hline $\begin{array}{l}\text { Társadalomföldrajzi } \\
\text { Tudományos Bizottság }\end{array}$ & 1707 & 40,20 & 180 & 10,54 \\
\hline $\begin{array}{l}\text { Természetföldrajzi } \\
\text { Tudományos Bizottság }\end{array}$ & 1230 & 39,79 & 304 & 24,72 \\
\hline $\begin{array}{l}\text { Földtudományok } \\
\text { Osztálya összesen }\end{array}$ & 6885 & 38,10 & 2331 & 33,86 \\
\hline $\begin{array}{l}\text { Regionális } \\
\text { Tudományok Bizottsága }\end{array}$ & 1377 & 34,52 & 142 & 10,31 \\
\hline
\end{tabular}

aránya. Érdemi változást hozhat, hogy 2015-ben a WoS bevezette a regionális jelentôségű folyóiratokat listázó Emerging Sources Citation Indexet (ESCI), amelynek köszönhetően például a továbbra is magyar nyelvú publikációkat megjelentető Tér és Társadalom folyóirat is WoS indexelést kapott.

Az MTA doktori habitusvizsgálatának tudománymérési követelményei mindenestre a fent vázolt jelenséget többé-kevésbé figyelembe is veszik, hiszen míg az ásvány- és kőzettan, geokémia, földtan, geofizika, meteorológia, paleontológia szakterületek esetében minimumkövetelményként 12 SCI/Scopus indexeléssel rendelkező publikációt fogalmaznak meg elvárásként, addig a bányászat, geodézia és geoinformatika, valamint természetföldrajz szakterületek esetében csak 8-at, a társadalomföldrajz esetében pedig csak 6-ot. Ezen a ponton azért érdemes egy hipotetikus felvetéssel élni: a fentebb vázolt kvantitatív követelmények vajon a tényeket veszik-e figyelembe, vagy generálják-e a tényeket? Vajon azért magas-e egy adott szakterület kutatójának WoS indexelésű folyóiratcikkeinek a száma 
(hogy maradjunk a példánál), mert esetében és szakterületén egyébként is bevett gyakorlat döntően WoS indexelésú folyóiratokban publikálni (és végső soron ezt veszi figyelembe a habitusvizsgálat kritériumrendszere), vagy azért magas, mert a vele szemben támasztott tudománymetriai követelmények is magasak? Az ok-okozati kapcsolatoknak ez a fajta elméleti megközelítése természetesen fordított viszonylatban is múködik.

Bár a jelen közleménynek nem célja definíciós kérdésekbe bocsátkozni, azt azért - mintegy nem elhanyagolható mellékszálként - érdemes megemlíteni, hogy a Földtudományok Osztálya a doktori habitusvizsgálat tudománymérési követelményei esetében más indikátorok kimutatását kéri, mint amit az MTMT szakterületi táblázata valójában szolgáltat. Az osztály a követelmények között ugyanis a Science Citation Index (SCI) és Social Sciences Citation Index (SSCI) által listázott folyóiratcikkek számának összesítését várja el, miközben az MTMT a teljes WoS állományból merít, és így többek között az ESCI folyóiratokban publikált cikkeket is beleszámolja az indikátor értékébe. Továbbá az sem teljesen világos, hogy mondjuk egy társadalomföldrajzos kutató a tudományos teljesítményének kimutatása érdekében miért ne számolhatná el a SCI indexelésú folyóiratcikkét, vagy egy geodéta a SSCI folyóiratban megjelent cikkét (amit a valóságban egyébként mindannyian megtesznek). Sokat könnyít a fentebb vázolt ellentmondásos helyzeten, hogy valamennyi szakterület esetében lehetséges a Scopus-ban indexelt folyóiratcikkek elszámolása is, márpedig GAVEL, Y.-ISELID, L. (2008) kutatása szerint a SCI/SSCI által listázott folyóiratok 84\%-a megtalálható a Scopus-ban is. A legújabb fejlemények azonban tovább bonyolítják a helyzetet, hiszen Magyarország 2019. január 1-jétől lemondta a Scopus adatbázis előfizetését (2019. január 11-től nem is érhetô el), a Scopus azonosítók pedig szerencsés esetben legfeljebb az EBSCO-ból nyerhetők ki, vagy néhány magán-előfizetőnél kutathatók fel. Ez azt jelenti, hogy jelen körülmények között a kutatók nemzetközi láthatóságának kimutatása kapcsán kizárólag a SCI, SSCI, ESCI (és néhány további, itt nem ismertetett) indexet felvonultató, az MTA és az MTMT páros által nem koherensen értelmezett WoS adatbázis lehet csak mérvadó.

Végezetül érdemes ismét összehasonlítani a Társadalomföldrajzi Tudományos Bizottság és a Regionális Tudományok Bizottsága ebben a témakörben vizsgált tudománymetriai adatait (3. táblázat). Az utóbbi bizottság kutatói a társadalomföldrajzos kutatóknál ugyan kisebb arányban publikálnak folyóiratcikkeket (40,2\%, illetve 34,52\%), de az eltérés nem szignifikáns, ráadásul a Földtudományok Osztálya egyes természettudományi irányultságú bizottságai esetében alacsonyabb összes publikáció/folyóiratcikk arányok is előfordulnak. Ami viszont mindkét bizottság esetében közel azonos, az a folyóiratcikkek nemzetközi láthatóságának viszonylagosan (legalábbis a többi bizottsággal összehasonlított) alacsony szintje, amely ebben a vonatkozásban ismét csak megerősíti a két szakterület - pontosabban a társadalomföldrajz - társadalomtudományi orientáltságát.

\section{A publikációk idézettségi hatása}

A publikációk idézettségi hatásának vizsgálata kétségtelenül központi szerepet tölt be a tudománymetriai kutatásokban, bár megítélése sok szempontból vitatott. SMART, J. C.-BAYER, A. E. (1986) szerint az idézések használata a kutatás minősége mérésének eszközeként azon a feltételezett egyszerú összefüggésen alapul, hogy egy kutató és közleménye minél nagyobb mértékben válnak idézetté, annál nagyobb mértékben járulnak hozzá a tudás fejlődéséhez. Más kutatók (NiEMinen, P. et al. 2006, LEYDESDORFF, L. et al. 2016, Michalska-Smith, M. J.-Allesina, S. 2017) kétségbe vonják, hogy a publikációk idézettségének mértéke valóban utal-e a megelőző kutatások minőségére, ám az akadémiai életben a hatás mérése az idézések száma, vagy annak valamilyen pontozása 
(pl. az impakt faktor értéke) alapján messzemenően elfogadottá vált (SARLI, C. et al. 2010, Carroll, C. 2016).

A publikációk idézettségi hatásának kimutatására természetesen a Földtudományok Osztálya is figyelmet fordít, és valamennyi szakterület esetében - nem hagyva figyelmen kívül a szakterületi sajátosságokat - beépíti azt a doktori habitusvizsgálat tudománymérési követelményeibe. Az ásvány- és kőzettan, geokémia, földtan, geofizika, meteorológia, paleontológia, valamint a társadalomföldrajz szakterületek 150-150 független idézésben határozzák meg a minimumkritériumot, a bányászat, geodézia és geoinformatika, valamint természetföldrajz szakterületcsoport pedig 120 független idézésben. Továbbá mind az ásvány- és kőzettan, geokémia, földtan, geofizika, meteorológia, paleontológia, mind a bányászat, geodézia és geoinformatika, természetföldrajz szakterületcsoportok definiálják a SCI- és Scopus-idézések minimumszámát (50, illetve 30), míg a társadalomföldrajz nem számol ezzel a szemponttal.

Az idézettségi hatás vizsgálata előtt szükséges tisztázni néhány korlátozást. Az MTMT a független és a függő idézések mellett kimutat egy ún. „nyilvános idézők” statisztikát is. A nyilvános idézések a független és a függó idézések értékének összege alapján kerülnek meghatározásra. A nyilvános idézések azonban valójában nemcsak független és függő idézéseket tartalmaznak, hanem önidézéseket is, ám utóbbiak közül sem mindegyiket. Az MTMT ugyanis a WoS-idézések automatikus importja után az önidézéseket függőnek minősíti, következésképpen beleszámolja a nyilvános idézések összegébe. Jogos lehet a felvetés, hogy a nyilvános idézések statisztikáját eleve nem is kellene figyelembe venni, hiszen az legfeljebb csak egy indikatív mutató lehet, viszont a WoS (lásd például a Researcher ID-t, illetve ma már a Publons-t) az idézések összegébe szintén beleszámolja az önidézéseket. Sőt az adott évben keletkezett, a megelőző két év meghatározó folyóiratcikkeire történő SCI/SSCI-önidézések beszámításra kerülnek a folyóiratok impakt faktor értékékeibe is. Amennyiben tehát WoS-idézések értékét is be kívánjuk emelni az elemzésbe, szükségünk lesz az MTMT-ben szereplő nyilvános idézések összegének használatára, elfogadva annak a fent említett korlátját. Továbbá ismét csak problémaként jelentkezik, hogy a doktori habitusvizsgálat tudománymérési követelményei - azokon a szakterületeken, ahol az lényeges - a SCI-idézések összegének kimutatását kérik (az SSCI-idézés, amely szintén összetevője az impakt faktornak, a követelmények szerint nem számolható el), míg az MTMT valójában a jóval nagyobb merítésû WoS-idézettség értékét mutatja ki.

Elfogadva a fenti korlátokat az idézettségi hatás vizsgálata a 4. táblázatban látható eredményekre vezetett. A legmagasabb egy publikációra vetített átlagos idézettséget (a nyilvános idézések összegéből levezetve) a Paleontológiai Tudományos Bizottságban keletkezett publikációk mutatják, míg a skála másik végén a Geodéziai és Geoinformatikai Tudományos Bizottság publikációinak átlagos idézettsége áll. Az is látható azonban, hogy a Paleontológiai Tudományos Bizottság kutatói által publikált közlemények idézéseinek alig több mint fele független idézés, ami részben azzal a ténnyel magyarázható, hogy a paleontológia szakterületen szerzett publikációk esetében viszonylag magas a társszerzők száma (igaz, még mindig alacsonyabb, mint néhány rokon szakterület esetében). Márpedig amikor egy társszerzős közlemény egyik szerzője a későbbiekben a korábbi közleményét idézi, akkor annak idézése számára ugyan önidézésként jelenik meg, ám minden más társszerző esetében függő idézésnek számít (LiN, W.-Y. C.-HuANG, M.-H. 2012), és az MTMT esetében beszámításra kerül a nyilvános idézések összegébe. A közleményeként sok társszerzővel rendelkező, illetve magas társszerzős publikációarányt mutató szakterületek (pl. geofizika, geokémia, meteorológia) esetében a független idézések aránya a nyilvános idézésekhez képest relatíve alacsonyabb (60-70\% közötti) értéket mutat. Ezzel szemben az inkább társadalomtudományi beállítottságú társadalomföldrajz szakterületre 
A Földtudományok Osztálya kutatói által publikált közlemények idézettségi hatása bizottsági szinten (2013-2017)

The citation impact of publications produced by researchers of the Section of Earth Sciences by committees (2013-2017)

\begin{tabular}{|c|c|c|c|c|c|}
\hline Tudományos bizottság & $\begin{array}{l}\text { A nyilvános } \\
\text { idézések } \\
\text { száma }\end{array}$ & $\begin{array}{c}\text { Az egy } \\
\text { publikációra } \\
\text { esố nyilvános } \\
\text { idézések } \\
\text { száma }\end{array}$ & $\begin{array}{l}\text { A független } \\
\text { idézések } \\
\text { száma }\end{array}$ & $\begin{array}{c}\text { A független } \\
\text { idézések } \\
\text { aránya a } \\
\text { nyilvános } \\
\text { idézésekhez } \\
\text { képest }(\%) \\
\end{array}$ & $\begin{array}{c}\text { Az egy } \\
\text { publikációra } \\
\text { esố független } \\
\text { idézések } \\
\text { száma }\end{array}$ \\
\hline $\begin{array}{l}\text { Bányászati } \\
\text { Tudományos Bizottság }\end{array}$ & 702 & 0,89 & 450 & 64,10 & 0,57 \\
\hline $\begin{array}{l}\text { Földtani } \\
\text { Tudományos Bizottság }\end{array}$ & 3321 & 1,68 & 2008 & 60,46 & 1,02 \\
\hline $\begin{array}{l}\text { Geodéziai } \\
\text { és Geoinformatikai } \\
\text { Tudományos Bizottság }\end{array}$ & 655 & 0,84 & 490 & 74,81 & 0,63 \\
\hline $\begin{array}{l}\text { Geofizikai } \\
\text { Tudományos Bizottság }\end{array}$ & 1804 & 1,30 & 1036 & 57,43 & 0,75 \\
\hline $\begin{array}{l}\text { Geokémiai, Ásvány- } \\
\text { és Kőzettani } \\
\text { Tudományos Bizottság }\end{array}$ & 6138 & 2,03 & 3839 & 62,54 & 1,27 \\
\hline $\begin{array}{l}\text { Meteorológiai } \\
\text { Tudományos Bizottság }\end{array}$ & 3280 & 1,84 & 2136 & 65,12 & 1,20 \\
\hline $\begin{array}{l}\text { Paleontológiai } \\
\text { Tudományos Bizottság }\end{array}$ & 2592 & 2,59 & 1409 & 54,36 & 1,41 \\
\hline $\begin{array}{l}\text { Társadalomföldrajzi } \\
\text { Tudományos Bizottság }\end{array}$ & 5059 & 1,19 & 4244 & 83,89 & 1,00 \\
\hline $\begin{array}{l}\text { Természetföldrajzi } \\
\text { Tudományos Bizottság }\end{array}$ & 4329 & 1,40 & 3088 & 71,33 & 1,00 \\
\hline $\begin{array}{l}\text { Földtudományok } \\
\text { Osztálya összesen }\end{array}$ & 27880 & 1,54 & 18700 & 67,07 & 1,03 \\
\hline
\end{tabular}

a magas nyilvános idézés/független idézés arány jellemző, ami tehát részben magyarázható a társszerzős közlemények alacsony arányával és a közleményenkénti kevesebb társszerzővel (ehhez még hozzá kell tenni, hogy az alacsonyabb WoS-indexelési arány miatt az önidézések MTMT által történő függő idézéssé minősítése is alacsonyabb értéket ér el). A Társadalomföldrajzi Tudományos Bizottságra jellemző 83,89\%-os nyilvános idézés/független idézés arány egyébként - nem meglepő módon - szignifikáns hasonlóságot mutat a Regionális Tudományok Bizottságára jellemző 84,35\%-os értékkel (6. ábra).

Végül nézzünk meg az összehasonlítás utolsó szempontját: a közlemények WoS-idézettségének arányát. Korábban megjegyeztem, hogy a WoS-idézéseket technikai okok miatt a nyilvános idézések összegével lehet összevetni. A 6.ábra azt mutatja, hogy a WoS-idézettség legmagasabb arányával a Geokémiai, Ásvány- és Kőzettani Tudományos Bizottság kutatói által publikált közlemények rendelkeznek: az összes idézés kétharmada a WoS-ban is megtalálható. A Természetföldrajzi, a Bányászati és a Társadalomföldrajzi Tudományos Bizottság kutatói által publikált közlemények WoS-idézettségi arányától eltekintve magas, 
60\%-ot közelítő vagy azt meghaladó WoS-idézettségi arány jellemző az osztály többi bizottságának publikációira is. A WoS-idézettség legalacsonyabb aránya a Társadalomföldrajzi Tudományos Bizottság esetében mutatható ki: a bizottság kutatói által publikált közlemények átlagos nyilvános idézés/WoS-idézés aránya éppen csak meghaladja a 12\%-ot, amivel legközelebb a nem osztálybeli Regionális Tudományok Bizottsága megfelelő értékéhez $(8,81 \%)$ áll. Ugyanakkor - szemben a Földtudományok Osztály más tudományos bizottságai által múvelt szakterületekkel - a doktori habitusvizsgálat tudománymérési követelményei a társadalomföldrajzi szakterület esetében nem is követelik meg a WoS (és a Scopus)-idézések beemelését a kritériumok közé (a jelenlegit megelőző habitusvizsgálati követelmények között egyébként még a társadalomföldrajz is kérte a SSCI- és Scopus-idézések kimutatását).

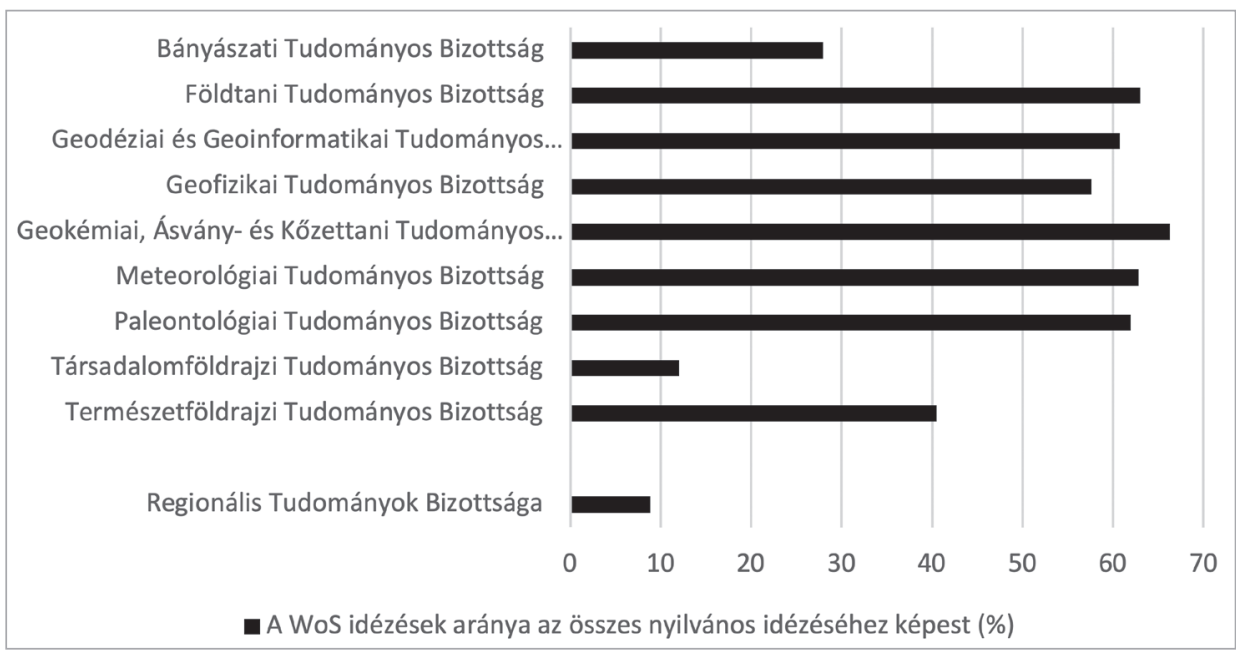

6. ábra A Földtudományok Osztálya tudományos bizottságaiban, valamint a Regionális Tudományok Bizottságában keletkezett publikációk WoS-idézéseinek aránya az összes nyilvános idézéshez képest (2013-2017)

Figure 6 The proportion of citations indexed in the WoS database to the total number of citations of publications produced by researchers of the Section of Earth Sciences (and that of the Regional Science Committee) by committees (2013-2017)

\section{Diszkusszió és konklúzió}

A tudományos teljesítmény mérése ún. akadémiai teljesítményindikátorok alapján mindig is része volt a tudományos életnek, azonban napjainkban egyre fokozottabb igény mutatkozik a kutatók, kutatócsoportok, intézmények, régiók és országok teljesítményének értékelésére, rangsorolására és összehasonlítására. Mivel az akadémiai teljesítményindikátorok elsősorban a tudományos publikációkkal állnak kapcsolatban, valamint az indexelő adatbázisokban a kutatók és a publikációk tudománymetriai adatai széleskörűen feldolgozásra és kimutatásra kerülnek, a tudományos teljesítményt legegyszerúbben a publikációs teljesítménnyel, a publikációk idézettségi hatásával lehet kifejezni.

A jelen tanulmányban áttekintettem a Földtudományok Osztálya MTMT-profillal rendelkező kutatóinak a 2013-2017-es időszakban publikált valamennyi tudományos közleményét és azok 2013-2018-as idézettségét, az adatokat pedig tudományos bizottságok szintjén összesítettem. A célom az volt, hogy egyrészt az osztály kutatóinak publikációs karakterisztikája alapján kimutassam az osztályban kimutatható inhomogenitást, más- 
részt hogy összehasonlítsam az osztály által a doktori habitusvizsgálat tudománymérési követelményeiben megfogalmazott szakterület-specifikus kritériumokat a kutatókra és a publikációkra jellemző tudománymetriai indikátorok valós értékével. Az elemzés során összefoglalva, és a fenti kérdésekre válaszolva a következő eredmények születtek.

1) A fajlagos kibocsátás (tehát az átlagos egy főre vetített publikációszám) esetében nem mutatható ki egyértelmú minta, ám annyi azért megállapítható, hogy a magas fajlagos kibocsátást produkáló szakterületek erósen természettudományi irányítottságúak. Az viszont sokkal alaposabb vizsgálatot igényelne, hogy miért a geodézia és geoinformatika, illetve a bányászat szakterület esetében a legalacsonyabb a fajlagos kibocsátás. Érdekesebb kérdés a szakterület-specifikus fajlagos kibocsátást a doktori habitusvizsgálat tudománymérési követelményeiben megfogalmazott minimumkövetelmények tükrében vizsgálni. Ez az elemzés ugyanis arra az eredményre vezet, hogy a minimumkövetelmények nem (feltétlenül) veszik figyelembe a szakterület-specifikus fajlagos kibocsátás valós értékét, ami azt eredményezi, hogy egyes szakterületek kutatói akár feleannyi idő alatt képesek a minimumkövetelményekben megfogalmazott publikációszámot teljesíteni, mint más szakterületek kutatói. Az osztályszinten mért egy fóre jutó kibocsátás átlaga 6,18 közlemény évente, az elemzés pedig azt mutatta ki, hogy egyes szerzők akár 20-30 közleményt is publikálnak évente (vagy legalábbis ennyi közleményben szerepelnek társszerzőként), ami azt jelenti, hogy 2-3 hetente újabb és újabb publikációval jelentkeznek. A darabszámokkal kapcsolatban érdemes kiragadni egy gondolatot KISs É. (2014) munkájából, aki azt vázolja, hogy a nyugat-európai és amerikai egyetemeken elég évente egy-két, esetleg három közleményt publikálni, viszont azokat a szakterületen rangosnak tartott folyóiratokban kell megjelentetni. Ez az elvárás teljesen jogos és reális, hiszen egy komoly kutatás akár években kifejezhető munkát is igényelhet. A hangsúly tehát nem a mennyiségen van (illetve kellene, hogy legyen), hanem a minőségen.

2) A kibocsátásban tapasztalt bizottsági szintű különbségek okai roppant összetettek, azt akár egyéni tényezők is befolyásolhatják, de a hátterében azért meghúzódik egy empirikusan is igazolt univerzális összetevő: a szakterület-specifikus társszerzőség-karakterisztika. A társszerzős publikációk aránya és a publikációnkénti társszerzőszám tudományterületenként, tudományáganként, vagy akár szakterületenként eltér. A társadalomtudományokra a társszerzős közlemények alacsony (bár a kurrens megfigyelések szerint egyre növekvő mértékû) aránya jellemző, míg a természettudományok esetében a magas arány és adott esetben nagy társszerzőszám tekinthető általánosnak. A fizika területén például már 5000 szerzős publikáció is született (CASTELVECCHI, P. 2015)! A magas társszerzős közlemények aránya és az átlagot meghaladó társszerzőszám jellemzi a Földtudományok Osztálya legtöbb szakterületét, míg a társadalomföldrajz szakterületre a társszerzős közlemények viszonylag alacsony aránya jellemző és a publikációnkénti társszerzőszám is alacsony. Mivel a társszerzőség-karakterisztika döntően befolyásolhatja a kibocsátást (és mint láttuk, az idézettséget is), a mennyiségre összpontosító jelzőszámok teljesítésekor a társadalomföldrajz kutatói eleve hátrányba kerülnek. Ezért több szakember (VAn Hooydonk, G. 1997, Bouyssou, D.-Marchant, T. 2016, Perianes-Rodriguez, A. et al. 2016) is azon a véleményen van, hogy a kutatók egyéni publikációs teljesítményének (kibocsátás, idézettség hatása stb.) számítását egész számok helyett törtekkel kellene megközelíteni, vagyis a többszerzős közlemények esetében a szerzők között az indikátorértékeket egyenlő arányban fel kell darabolni. Ezt a módot követve pl. egy 12 szerzős, 3 impakt faktoros cikk, amelyre eddig 20 idézés érkezett, a törtszámítás után 1/12 darab cikket, 0,25 impakt faktort és 1,67 idézést jelentene szerzőnként.

Ez a fajta megközelítés sem tekinthető teljesen „fairnek” (utalhatunk pl. az első szerző szerepének leértékelődésére), ám arra mindenképpen sarkallhatja a közlemény tényleges 
szerzőit, hogy valóban csak a kutatásban résztvevők nevét sorolják fel a közleményeken és tekintsenek el a „tiszteletbeli” szerzők nevének feltűntetésétől (KATZ, J. S.-MARTIN, B. R. 1997). Törtszámítással mindenesetre pontosabban kimutathatóvá válna a kutatók egyéni publikációs teljesítménye, ráadásul a különböző szakterületeken mutatkozó eltérő publikációs gyakorlatból származó különbségek is kiegyenlítődnének (vagy legalábbis a módszer abba az irányba hatna).

3) Az indikátorok között minden szakterület esetében súly helyeződik a folyóiratcikkek számára, igaz, közülük csak a nemzetközi relációban (a WoS, illetve a Scopus adatbázisokban) látható folyóiratcikkek számára. Az elemzés azt mutatta ki, hogy osztályszinten a publikációk valamivel több mint egyharmada kerül folyóiratcikként publikálásra, amelynek egészen pontosan egyharmada jelenik meg a WoS adatbázisban (a Scopus adatbázis elérhetősége megszűnt, következésképpen számolni sem lehet vele). Míg az első mutató (összes publikáció/folyóiratcikk) esetében a szakterület-specifikus arányok intervalluma $31 \%$ és $50 \%$ közötti, addig a második mutató (összes folyóiratcikk/WoS folyóiratcikk) esetében a skála szélső értékei $10 \%$ és 59\% között mozognak. Például a doktori habitusvizsgálat tudománymérési követelményei a geokémiai, ásvány- és kőzettani szakterület számára minimumkövetelményként 12 SCI folyóiratcikket fogalmaznak meg, míg a társadalomföldrajz szakterülettől 6 SSCI folyóiratcikket várnak el (az elemzésben a WoS vs. SCI/SSCI probléma, illetve a SCI vs. SSCI probléma részletesen bemutatásra került). A geokémiai, ásvány- és kőzettani szakterület kutatóinak minimumkövetelményként tehát mindössze kétszer annyi WoS folyóiratcikket kell produkálniuk, mint a társadalomföldrajzos kollégáiknak, miközben valójában egységnyi idő alatt 6,7-szeres köztük a kibocsátásbeli különbség, és nem a társadalomföldrajz kutatói javára. Bár a szakterület-specifikus minimumkövetelmények megfogalmazása nem áll összhangban a kutatók valós teljesítményével, annyi legalább pozitívum ként említhetô, hogy a szakterületek csoportosítása többé-kevésbé elfogadhatóan tükrözi azok nemzetközi láthatóságát (pl. a geodézia és geoinformatika szakterület WoS-láthatósága nagyjából azonos a természetföldrajzéval, és így tovább).

4) A publikációk idézettségi hatásában - részben a fentebb felsorolt okok miatt - szakterületenként szintén jelentős különbségek tapasztalhatók, ám azok mégsem követik a fenti mintákat. Például a magasan osztályátlag feletti fajlagos publikációs kibocsátással rendelkező földtan szakterület egy publikációra jutó független idézéseinek száma nagyjából az osztályátlag körül alakul, csakúgy, mint az egyébként messze alacsonyabb fajlagos kibocsátású társadalomföldrajz szakterületnek. Tekintettel arra, hogy az egyes szakterületek esetében közel azonos az egy publikációra jutó független idézések száma, a szakterületenkénti 150 független idézés a legtöbb esetben elfogadhatónak tûnik. Kivételt a bányászat, illetve a geodézia és geoinformatika szakterületek jelentenek, ahol az egy publikációra jutó független idézések száma jóval átlag alatti, így indokolt a két szakterület számára a többi szakterülethez képest $20 \%$-kal alacsonyabb minimumkövetelmény felállítása (végsô soron a természetföldrajz sem emelkedik ki látványosan ebből a csoportból). Sokkal érdekesebb a WoS-idézések helyzete (itt újra megjelenik a SCI/SSCI következetlenség), vagyis annak kérdése, hogy a tudományos publikációknak milyen a nemzetközi fogadtatása. Ebben a vizsgálati szakaszban egy elég kritikus, bár az érdemi következtetéseket szignifikánsan nem befolyásoló tényezôvel is számolni kell: a független idézések összege helyett az összehasonlítás alapját a nyilvános idézések száma jelenti. Az eredmény pedig az, hogy a bányászat, a természetföldrajz, és a társadalomföldrajz szakterületek WoS-idézettsége elmarad az osztály többi szakterületén tapasztalható 50\% körüli, vagy azt meghaladó WoS-idézettségi aránytól. A társadalomföldrajz szakterületen a nyilvános idézéseknek mindössze a 12\%-a WoS-idézés, amely részben módszertani okokkal magyarázható - az MTMT a nyilvános idézésekben a függő idézéseket, sőt a WoS-önidézéseket is beszámolja, 
márpedig azok számát a társszerző-karakterisztika döntően befolyásolja -, részben pedig azzal a ténnyel, hogy a társadalomföldrajz szakterületen keletkezett publikációk nemzetközi láthatóságának szintje relatíve alacsonyabb. Mindezek tükrében talán nem is meglepő, hogy a társadalomföldrajz szakterületen a minimumkövetelmények sorából kikerült a WoS/Scopus-idézések indikátorértéke (az ezzel kapcsolatos ok-okozati feltételezést a jelen közleményben részletesen is vázoltam).

A konklúzió konklúziója pedig az, hogy az MTA doktori habitusvizsgálatának tudománymérési követelményeiben megfogalmazott szakterület-specifikus indikátorértékek több esetben sem megfelelően reflektálnak a kutatók tényleges publikációs karakterisztikájára és teljesítményére. A jelen tanulmányban a nyilvánosan elérhető, osztályszintű MTMT-adatok kerültek feldolgozásra, a következtetések pedig annak alapján lettek levonva, ám egy hivatalos, az osztály által kezdeményezett felülvizsgálat (amelyben az MTMT is partner) bizonyára pontosabb eredményekre vezethet, és talán hozzájárulhat a doktori habitusvizsgálat tudománymérési követelményeinek pontosításához.

\section{CSOMÓs GYÖRGY \\ DE MK Építómérnöki Tanszék, Debrecen \\ csomos@eng.unideb.hu}

\section{IRODALOM}

BOUYSSOU, D.-MARCHANT, T. 2016: Ranking authors using fractional counting of citations: An axiomatic approach. - Journal of Informetrics 10. 1. pp. 183-199.

Braun, T.-GlänZEL, W.-Schubert, A. 1989: Some data on the distribution of journal publication types in the science citation index database. - Scientometrics 15. 5-6. pp. 325-330.

CARroll, C. 2016: Measuring academic research impact: creating a citation profile using the conceptual framework for implementation fidelity as a case study. - Scientometrics 109. 2. pp. 1329-1340.

Castelvecchi, D. 2015: Physics paper sets record with more than 5,000 authors. - Nature News 15 May 2015.

Coomes, O. T.-Moore, T.-Paterson, J.-Breau, S.-Ross, N. A.-Roulet, N. 2013: Academic performance indicators for departments of geography in the United States and Canada. - The Professional Geographer 65. 3. pp. 433-450.

Csaba L.-Szentes T.-Zalai E. 2014: Tudományos-e a tudománymérés? Megjegyzések a tudománymetria, az impakt faktor és MTMT használatához. - Magyar Tudomány 175. 4. pp. 442-466.

Csomós Gy. 2016: A magyarországi tudományos publikálás néhány sajátossága: következtetések egy indexelő adatbázis alapján. - Magyar Tudomány 177. 2. pp. 226-235.

Csomós Gy. 2019: A társadalomföldrajz tudományrendszertani besorolásának hazai és nemzetközi gyakorlata. - Földrajzi Közlemények 143. 1. pp. 1-11.

Gauffriau, M.-Larsen, P. O.-Maye, I.-Roulin-Perriard, A.-von Ins, M. 2008: Comparisons of results of publication counting using different methods. - Scientometrics 77. 1. pp. 147-176.

GAVEL, Y.-ISELID, L. 2008: Web of Science and Scopus: a journal title overlap study. - Online Information Review 32. 1. pp. 8-21.

GorRAiz, J.-GUMPENBERGER, C.-GLADE, T. 2016: On the bibliometric coordinates of four different research fields in Geography. - Scientometrics 107. 2. pp. 873-897.

Hansen, N. M.-Quigley, J. M. 1976: An introduction to regional science by Walter Isard. - Land Economics 52. 3. pp. 407-413.

Holl A.-MAKara G.-MicsiK A.-KovÁcs L. 2014: MTMT: The Hungarian Scientific Bibliography. - http:// eprints.sztaki.hu/8020/

INGWERSEN, P. 2000: The international visibility and citation impact of Scandinavian research articles in selected social science fields: the decay of a myth. - Scientometrics 49. 1. pp. 39-61.

ISARD, W. 2003: History of regional science and the Regional Science Association International: the beginnings and early history. - Springer, Berlin-Heidelberg. 274 p.

JACSO, P. 2005: As we may search - Comparison of major features of the Web of Science, Scopus, and Google Scholar citation-based and citation-enhanced databases. - Current Science 89. 9. pp. 1537-1547. 
KATZ, J. S.-MARTin, B. R. 1997: What is research collaboration? - Research Policy 26. 1. pp. 1-18.

KIss É. 2014: A tudományos minősítés és tudományos teljesítményértékelés nemzetközi tapasztalatai társadalomföldrajzi nézőpontból. - Földrajzi Közlemények 138. 3. pp. 241-250.

Leydesdorff, L.-Bornmann, L.-Comins, J. A.-Milojevic,'S. 2016: Citations: indicators of quality? The impact fallacy. - Frontiers in Research Metrics and Analytics 1. pp. 1-15.

LIN, W.-Y.C.-HUANG, M.-H. 2012: The relationship between co-authorship, currency of references and author self-citations. - Scientometrics 90. 2. pp. 343-360.

Maisonobe, M.-Grossetti, M.-Milard, B.-JÉGOU,L.-Eckert, D. 2017: The global geography of scientific visibility: a deconcentration process (1999-2011). - Scientometrics 113. 1. pp. 479-493.

Mali, F.-Kronegger, L.-Doreian, P.-Ferligoj, A. 2012: Dynamic scientific co-authorship networks. - In: Scharnhorst, A.-Börner, K.-VAn Den BesselaAr, P. (szerk.): Models of science dynamics. - Springer, Berlin, Heidelberg. pp. 195-232.

Michalska-Smith, M. J.-Allesina, S. 2017: And, not or: quality, quantity in scientific publishing. - PLoS ONE 12.6. e0178074.

Mongeon, P.-PAul-Hus, A. 2016: The journal coverage of Web of Science and Scopus: a comparative analysis. - Scientometrics 106. 1. pp. 213-228.

Newman, M. E. 2001: Scientific collaboration networks. I. Network construction and fundamental results. - Physical Review E 64. 1. 016131.

NiEMinen, P.-CARPENTER, J.-RUCKER, G.-SChUMACHER, M. 2006: The relationship between quality of research and citation frequency. - BMC Medical Research Methodology 42. pp. 1-8.

Perianes-Rodriguez, A.- Waltman, L.-VAn Eck, N. J. 2016: Constructing bibliometric networks: A comparison between full and fractional counting. - Journal of Informetrics 10. 4. pp. 1178-1195.

Probáld F. 2007: Társadalomföldrajz és regionális tudomány. - Tér és Társadalom 21. 1. pp. 21-33.

PRoBÁld F. 2018: Magyar társadalomföldrajz - mindinkább angolul? - Földrajzi Közlemények 142. 3. pp. $247-254$.

Rey-Rocha, J.-MARtín-SEMPERE, M. J. 2004: Patterns of the foreign contributions in some domestic vs. international journals on Earth Sciences. - Scientometrics 59. 1. pp. 95-115.

SARli, C.-Dubinsky, E.-Holmes, K. 2010: Beyond citation analysis: a model for assessment of research impact. - Journal of the Medical Library Association 98. pp. 17-23.

SMART, J. C.-BAYER, A. E. 1986: Author collaboration and impact: a note on citation rates of single and multiple authored articles. - Scientometrics 10. 5-6. pp. 297-305.

SzEGEDY-MASZÁK M. 2015: Folyóirat vagy könyv: mérlegen a tudományos teljesítmény. - Magyar Tudomány 176. 4. pp. 404-409.

VAN HoOYDONK, G. 1997: Fractional counting of multiauthored publications: consequences for the impact of authors. - Journal of the American Society for Information Science 48. 10. pp. 944-945.

WANG, L.-LIU, Z. 2014: A bibliometric analysis on rural studies in human geography and related disciplines. - Scientometrics 101. 1. pp. 39-59.

YANG, K.-MeHO, L. I. 2007: Citation analysis: a comparison of Google Scholar, Scopus, and Web of Science. - Proceedings of the American Society for Information Science and Technology 43. 1. pp. 1-15.

\section{Internetes források}

King's College London, 2019: Library Service, Research support, Evaluating Research, Citation Analysis, Google Scholar. - www.kcl.ac.uk/library/researchsupport/evaluatingresearch/citationanalysis/googlescholar 